๑П. Ф. Шаганов

Донещький нащіо нальний медичний університет, Лиман

\title{
КЛІНІКО-АНАМНЕСТИЧНА ХАРАКТЕРИСТИКА ПАЦІЕНТОК ІЗ ТРУБНО- ПЕРИТОНЕАЛЬНИМ БЕЗПЛІДДЯМ ТА РЕЗУЛЬТАТИ МОРФОЛОГІЧНОГО ДОСЛІДЖЕННЯ СПАЙОК У ДАНОЇ КАТЕГОРІЇ ПАЦІЕНТОК
}

\begin{abstract}
Мета дослідження - вивчити анамнез, клінічні прояви і гістологічну структуру спайок у пацієнток із трубно-перитонеальним безпліддям.

Матеріали та методи. Було обстежено 66 жінок із трубно-перитонеальним безпліддям і 30 здорових жінок. В обстежених жінок збирали анамнез, оцінювали клінічні прояви і проводили додаткові обстеження. Спайковий процес органів малого таза оцінювали за J. Нulka та співавт. Критерієм включення в дослідження була наявність спайкового процесу 2 і 3 ступенів. Всім хворим проведено ультразвукове сканування органів малого таза для оцінки наявності ознак спайкового процесу. Під час лапароскопії виконували забір зразків спайок, серійні гістологічні зрізи після підготовки фарбували гематоксиліном та еозином, пікрофуксином за Ван-Гізоном і фрукселіном за Хартом.

Результати дослідження та їх обговорення. Проведене дослідження показало, що пацієнтки з трубно-перитонеальним безпліддям, на відміну від контрольної групи, значно частіше мали оперативні втручання на органах черевної порожнини і малого таза (причому повторні операції були в кожному третьому випадку), а також запальні захворювання репродуктивних органів. Автори показали, що більшість обстежених мали вагітності в анамнезі, але зареєстровані відмінності в структурі: більшість жінок контрольної групи народжували, тоді як в обстежених із безпліддям переважали позаматкові вагітності й аборти. Всі обстежені жінки мали спайковий процес, який був підтверджений при проведенні лапароскопії. Дослідження продемонструвало, що УзД не є неінсормативним методом для підтвердження зазначеної патології. Проведене гістологічне дослідження спайок виявило наявність відмінності в їх структурі залежно від етіологічного фрактора (оперативне втручання або запальний процес), а також ознаки запального процесу, незважаючи на відсутність його клінічних ознак, у жінок без оперативних втручань в анамнезі.
\end{abstract}

Висновок. Автори дослідження дійшли висновку, що необхідно враховувати наявність або відсутність хронічного запального процесу при розробці підходів вторинної профрілактики утворення спайок у жінок із трубно-перитонеальним безпліддям на етапі післяопераційної реабілітації та лікування безпліддя.

Ключові слова: спайки; трубно-перитонеальне безпліддя; гістологічне дослідження.

КЛИНИКО-АНАМНЕСТИЧЕСКАЯ ХАРАКТЕРИСТИКА ПАЦИЕНТОК С ТРУБНО-ПЕРИТОНЕАЛЬНЫМ БЕСПЛОДИЕМ И РЕЗУЛЬТАТЫ МОРФОЛОГИЧЕСКОГО ИССЛЕДОВАНИЯ СПАЕК У ДАННОЙ КАТЕГОРИИ ПАЦИЕНТОК

Цель исследования - изучить анамнез, клинические проявления и гистологическую структуру спаек у пациенток с трубно-перитонеальным бесплодием.

Материалы и методы. Было обследовано 66 женщин с трубно-перитонеальным бесплодием и 30 здоровых женщин. У обследованных женщин собирали анамнез, оценивали клинические проявления и проводили дополнительные обследования. Спаечный процесс органов малого таза оценивали по J. Hulka и соавт. Критерием включения в исследование было наличие спаечного процесса 2 и 3 степеней. Всем больным проведено ультразвуковое сканирование органов малого таза для оценки наличия признаков спаечного процесса. Во время лапароскопии выполняли забор образцов спаек, серийные гистологические срезы после подготовки окрашивали гематоксилином и эозином, пикрофуксином по Ван-Гизону и фрукселином по Харту.

Результаты исследования и их обсуждение. Проведенное исследование показало, что пациентки с трубно-перитонеальным бесплодием, в отличие от контрольной группы, значительно чаще имели оперативные вмешательства на органах брюшной полости и малого таза (причем повторные операции были в каждом третьем случае), а также воспалительные заболевания репродуктивных органов. Авторы показали, что большинство обследованных имели беременности в анамнезе, но зарегистрированы различия в структуре: большинство женщин контрольной группы рожали, тогда как у обследованных с бесплодием преобладали внематочные беременности и аборты. Все обследованные женщины имели спаечный процесс, который был подтвержден при проведении лапароскопии. Исследование показало, что УЗИ не является неинсормативным методом для подтверждения указанной патологии. Проведенное гистологическое исследование спаек выявило наличие различия в их структуре в зависимости от этиологического фактора (оперативное вмешательство или воспалительный процесс), а также признаки воспалительного процесса, несмотря на отсутствие его клинических признаков, у женщин без оперативных вмешательств в анамнезе.

Вывод. Авторы исследования пришли к выводу, что необходимо учитывать наличие или отсутствие хронического воспалительного процесса при разработке подходов вторичной профилактики образования спаек у женщин с трубно-перитонеальным бесплодием на этапе послеоперационной реабилитации и лечения бесплодия.

Ключевые слова: спайки; трубно-перитонеальное бесплодие; гистологическое исследование.

SOME PECULIARITIES OF HISTORY AND CLIINICAL DATA OF PATIENTS WITH TUBOPERITONEAL INFERTILITY AND RESULTS OF THE MORPHOLOGICAL RESEARCH OF ADHESIONS IN THIS CATEGORY OF PATIENTS

The aim of the study - to learn the history, clinical manifestations and histological structure of adhesions in patients with tuboperitoneal infertility. 
Materials and Methods. There were examined 66 women with tuboperitoneal infertility and 30 healthy women. The anamnesis was collected, clinical manifestations, and additional examinations were performed. Adhesions of the pelvic organs were evaluated by J. Hulka et al. The inclusion criterion in the study was the presence of 2 and 3 degrees adhesions. All patients underwent an ultrasound scan of the pelvic organs to assess the presence of signs of adhesions. During laparoscopy adhesions were sampled; serial histological sections were stained with hematoxylin and eosin, with picrofuchsin according to van Gison and fukselin according to Hart.

Results and Discussion. The study showed that patients with tuboperitoneal infertility, unlike the control group, had surgery on the abdominal cavity and pelvic organs much more often (and repeated operations were carried out in every third case), as well as inflammatory diseases of the reproductive organs. The authors showed that most of the surveyed women had pregnancies in history, but differences in structure were recorded: the majority of women in the control group gave birth, whereas among the patients with infertility ectopic pregnancies and abortions prevailed. All examined women had adhesions, which was confirmed during laparoscopy. The study showed that ultrasound is not an informative method to confirm this pathology. A histological study of adhesions revealed the presence of differences in their structure depending on the etiological factor (surgery or inflammation), as well as signs of inflammation in women without surgical interventions in history, despite the absence of its clinical manifestations.

Conclusion. The authors of the study concluded that it is necessary to take into account the presence or absence of a chronic inflammatory process when developing approaches for the secondary prevention of the formation of adhesions in women with tuboperitoneal infertility at the stage of postoperative rehabilitation and infertility treatment.

Key words: adhesions; tuboperitoneal infertility; histological examination.

ВСтУП. У гінекологічній практиці проблема наявності спайок у ділянці малого таза досить розповсюджена [1-3]. Дані багатьох авторів вказують, що наявність спайок негативно впливає на стан здоров'я пацієнток [4]. Це пов'язано з тим, що наявність навіть незначних за розмірами зрощень призводить до порушення фрункції маткових труб, у результаті чого складаються передумови для розвитку трубно-перитонеального безпліддя або ектопічної вагітності [5]. Спайковий процес може порушувати анатомічні взаємовідношення органів малого таза, матки, придатків, функцію суміжних органів - прямої кишки, сечового міхура, до розвитку кишкової непрохідності [6].

При вивченні анамнезу жінок з наявністю спайок органів малого таза встановлено, що до 60 \% з них страждають від безпліддя [2, 7], невиношування вагітності [8], у більшості з них мають місце запальні процеси геніталій і різні форми порушень менструального циклу [9].

МЕТА ДОсЛІДЖЕННЯ - вивчення анамнезу, клінічних проявів та гістологічної структури пацієнток із трубноперитонеальним безпліддям.

МАТЕРІАЛИ ТА МЕТОДИ. БУЛо обстежено 66 жінок із трубно-перитонеальним безпліддям та 30 здорових жінок. Пацієнтки з безпліддям були випадковим чином розподілені на 2 групи: основну (1 група, 34 жінки) та порівняння (2 група, 32 жінки). Здорові обстежені склали групу контролю (3 група). Всі обстежені пацієнтки були у віці від 25 років до 42 років, що пов'язано з критеріями відбору пацієнток у дослідження, а саме: оперативне втручання $€$ останнім етапом обстеження та лікування жінок із неплідністю. Це пов'язано з тим, що об'єктивним критерієм наявності або відсутності сполук у черевній порожнині є їх візуалізація. Вона можлива при лапаротомії або лапароскопії. Жінки в контрольну групу відбиралися за принципом випадок-контроль, де критерієм відбору був саме вік обстежених.

В обстежених жінок збирали анамнез, оцінювали клінічні прояви та проводили додаткові обстеження.

Існує значна кількість класифікацій спайкового процесу. Нами обрана класифрікація спайкового процесу органів малого таза за J. Hulka і співавт. [10]. У цій класифікації розрізняють 4 ступені спайкового процесу і враховують непрохідність маткових труб: 1 ступінь - спайки мінімальні, труби прохідні, видно велику частину яєчника; 2 ступінь - більше 50 \% поверхні яєчника вільно, ампулярна оклюзія із збереженням складок; 3 ступінь - вільно менше 50 \% поверхні яєчника, ампулярна оклюзія з руйнуванням складок; 4 ступінь - поверхня яєчника не видна, двосторонній гідросальпінкс [11]. Критерієм включення у дослідження була наявність спайкового процесу 2 та 3 ступенів. Жінки 31 ступенем були виключені у зв'язку 3 наявністю прохідності труб та можливості самостійного настання вагітності, а 4 ступеня - тому, що, згідно 3 міжнародними стандартами, гідросальпінкси знижують імовірність настання вагітності та потребують видалення, що призводить до виникнення прямих показань до екстракорпорального запліднення.

Усім хворим проведено ультразвукове сканування органів малого таза, що виконувалося на 5-10 день менструального циклу вагінальним датчиком частотою 7,5 мГц на апараті Aloka SSD-680 (Японія). На ехограмах оцінювали форму і розміри матки, яєчників, наявність ознак спайкового процесу.

Спайки малого таза для дослідження отримували при проведенні лапароскопії за такою методикою: спайка малого таза витягується через троакар, промивається у фрізіологічному розчині (0,9 \% хлориду натрію) 3 подальшою консервацією матеріалу в розчині формаліну (50 мл) протягом 24 год; надалі спайка консервується в 70 \% етиловому спирті до моменту проведення дослідження. Після дегідратації шматочки заливали в парафрін за стандартною методикою. На ротаційному мікротомі Microm HM325 з системою переносу зрізів STS (Carl Zeiss, Німеччина) виготовляли серійні гістологічні зрізи товщиною 3-4 мкм, які потім фрарбували гематоксиліном та еозином за стандартною методикою, пікрофуксином за Ван-Гізоном, забарвлення фрукселіном за Хартом на визначення еластичних волокон. Мікроскопію препаратів проводили на мікроскопі Olympus AX70 Provis (Olympus, Японія) за допомогою програми аналізу зображення Analysis 3.2 Pro (Soft Imaging, Німеччина) відповідно до рекомендацій виробника програмного забезпечення.

Обробку даних проводили з використанням методів варіаційної статистики, $X^{2}$-критерію і точного критерію Фішера.

Середній вік обстежених склав $(33,25 \pm 2,68) ;(35,18 \pm 1,73)$ та $(32,43 \pm 2,59)$ років відповідно по групах. Близько половини пацієнток були віком 30-35 років, а після $40-$ 
лише 1 в основній та 2 в групі порівняння. Вірогідної різниці між обстеженими групами за віковим складом та середнім віком не зареєстровано ( $p>0,05)$. За соціальним станом жінки розподілялися таким чином: більша частка обстежених були жительками міста (73,53; 68,75 \% та 70,00 \% відповідно по групах) з середньою (23,53; 21,88 \% та 10,00 \%) або вищою освітою (52,94; 46,88 \% та 53,33 \%). Достовірної різниці між групами за місцем мешкання та освітою не винайдено ( $p>0,05)$.

Жінки з трубно-перитонеальним безпліддям не відрізнялися за частотою соматичної патології, а саме: частіше за все вони мали в анамнезі захворювання шлунково-кишкового тракту (20,59 \% та 15,63 \% у групах 1 та 2 відповідно, р>0,05), сечовивідних шляхів $(17,65 \%$ та $21,88 \%$, p>0,05) та різні види алергій $(14,71 \%$ та $18,75 \%$, p>0,05). Відсутність соматичних захворювань у жінок контрольної групи була пов'язана з критеріями їх відбору.

РЕЗУЛЬТАТИ ДОСЛІДЖЕННЯ ТА ЇХ ОБГОВОРЕННЯ. Аналіз анамнезу щодо оперативних втручань показав, що здорові жінки репродуктивного віку мали зазвичай у минулому тонзилектомію (6,67 \%) та апендектомію (3,33 \%). У той час як у пацієнток із трубно-перитонеальним безпліддям у кожному третьому випадку були операції на тазових органах (32,35 \% та 28,13\% відповідно по групах, $\mathrm{p}>0,05)$. Треба відзначити, що частина жінок основної та групи порівняння мали повторні операції на тазових органах (36,36 \% та 22,22 \% серед всіх прооперованих на органах малого таза, p>0,05). Лідируючою причиною операцій у жінок із трубно-перитонеальним безпліддям були позаматкова вагітність та запальні утворення в ділянці придатків матки. За даними інших дослідників, жінки 3 перитонеальною формою безпліддя у 30-40 \% випадків мали оперативні втручання на органах малого таза $[12,13]$.

Вік менархе всіх обстежених суттєво не відрізнявся і склав $(12,33 \pm 0,42) ;(12,45 \pm 0,37)$ та $(12,58 \pm 0,51)$ року ( $>>0,05)$. Тривалість менструації та менструального циклу також була зіставна між групами $(p>0,05)$. У той час як у характері менструальної функції виявлено деякі відмінності між жінками з трубно-перитонеальним непліддям та без такого, а саме: перші частіше мали рясні (23,53 \% та $18,75 \%$ порівняно з 0 \% в контролі, p<0,05) і болючі (32,35 \% та 21,87 \% порівняно з 6,67\%, p<0,05) менструації.

Вивчення гінекологічного анамнезу обстежених не виявило різниці між основною та групою порівняння ( $>>0,05)$. У жінок контрольної групи гінекологічної патології в анамнезі не виявлено у зв'язку з критеріями відбору пацієнток у дослідження (жінки повинні були бути гінекологічно здоровими). Дві третини жінок основної та групи порівняння мали в анамнезі запальні захворювання статевих органів $(73,53 \%$ та $65,62 \%$, p>0,05), та в половини з них вони були повторні (41,17 \% та 31,25 \% від загальної кількості обстежених, p>0,05).

Результати досліджень інших авторів показали, що майже всі (90 \%) пацієнтки з трубно-перитонеальною формою безпліддя мають в анамнезі запальні процеси придатків матки, та третина з них - часті їх загострення [7, 14-16]. На нерідке виникнення трубно-перитонеального безпліддя після перенесеного сальпінгоофориту (33-70,0 \%) вказує багато дослідників [7, 15, 17]. Вважається, що організм реагує серією захисних специсрічних чи неспецифрічних реакцій на деякі бактерії [18-21]. Отже, у патогенезі формування й прогресування спайкової хвороби значну роль відіграють хронічні процеси тазових органів.

Ні одна з жінок не хворіла на ендометріоз, тому що в дослідження включали жінок з трубно-перитонеальним непліддям, а ендометріоз є окремим фактором виникнення неплідності. Відповідно до критеріїв включення в дослідження, всі обстежені мали безпліддя, причому у значної частки з них воно було вторинне (у 67,65 \% та 71,88 \% відповідно по групах, p>0,05). 5 жінок $(14,71 \%) 3$ основної та 3 (9,38 \%) - $з$ групи порівняння були прооперовані у зв'язку з кістами яєчників, $(p>0,05)$. Додатковим несприятливим фактором було те, що в більшості випадків операція була проведена у зв'язку з апоплексією кісти. У частини з прооперованих (4 та 3 або 11,76 \% та 9,38 \% відповідно по групах, p>0,05) причиною втручання була позаматкова вагітність. Майже всі пацієнтки з безпліддям мали патологію шийки матки в минулому (73,53 \% та $81,25 \%$, р>0,05), причому в більшості випадків це були цервіцити або дисплазія слабкого ступеня.

Аналіз репродуктивного анамнезу пацієнток показав, що значна кількість з них мали вагітності у своєму житті (67,65; 71,88 \% та 90,0 \% відповідно по групах), але існувала суттєва різниця в їх структурі. А саме: більшість жінок контрольної групи народжували (70,0% порівняно 3 $20,59 \%$ і 28,13 \% в 1-й та 2-й групах, p<0,05), тоді як в обстежених з безпліддям переважали позаматкові вагітності $(11,76 \%$ і 9,36 \%, p<0,05) й аборти (мимовільні - 14,71 \% та 21,88; медичні - 26,47 \% та 25,00 \%, p<0,05).

Таким чином, пацієнтки основної та групи порівняння відрізнялися від контрольної групи наявністю оперативних втручань на органах черевної порожнини та малого таза, значною частотою повторних операцій, а також запальних захворювань репродуктивних органів.

Усім обстеженим жінкам було проведено ультразвукове дослідження для виявлення ознак злукового процесу. Всі ознаки були розподілені на дві категорії: абсолютні та відносні. До абсолютних були віднесені такі, які дозволяють візуалізувати або топографувати злуки. А саме: наявність при ультрасонографрічному обстеженні крапкових або лінійних ехопозитивних тіней у проекції органів малого таза $[22,23]$ та пальпаторна локалізація сполучнотканинних тяжів при бімануальному гінекологічному обстеженні. До відносних ознак були віднесені фріксований зсув внутрішніх статевих органів від нормального анатомічного положення, що реєструвався при гінекологічному або ультразвуковому обстеженні.

За даними літератури, товщина спайки для її візуалізації при ультрасонограсрічному обстеженні повинна бути не менше 5-6 мм, інакше не буде переломлення ультразвукової хвилі на межі між тканинами [22, 23]. Злуки з такими параметрами у порожнині малого таза є досить рідким явищем. Тому не дивно, що нами зареєстрована різниця в частоті виявлення злукового процесу за даними УзД та лапароскопії. Так, лінійні (64,71 \% та 78,13 \%) і дрібнокраплинні (79,41 \% та 75,0 \%) злуки візуалізовано у більшості жінок під час операції, у третини виявлено виражений параоваріальний фріброз (32,35 \% та 43,75 \%), тоді як при УЗД злуки виявлялися в 3-5 разів рідше $(p<0,05)$. щодо такої ознаки, як зміщення органів малого таза, то УЗД виявилося досить інформативним й нами не було 
зареєстровано вірогідної різниці за цим показником за даними УЗД та лапароскопії ( $p>0,05)$.

Кількість жінок з 2 та 3 ступенями спайкового процесу була майже однакова в обох обстежених групах, але пацієнток 33 ступенем було дещо більше (55,88 \% порівняно $з$ 44,12 \% та 62,50 \% порівняно з 37,50 \% відповідно по групах, $p>0,05)$.

Отже, всі обстежені жінки мали злуковий процес, який було підтверджено при проведенні лапароскопії, тоді як УзД виявилося неінформативним методом для підтвердження вказаної патології.

Під час лапароскопії були взяти зразки злук та проведено їх гістологічне дослідження. Необхідно зазначити, що нами винайдено деякі відмінності в гістологічній структурі злук між жінками з оперативними втручаннями в анамнезі та без таких. Так, у жінок з операціями на тазових органах спайки були представлені щільною або дуже щільною сполучною тканиною (рис. 1) з осередками надлишку колагенових волокон у вигляді пучків, що йдуть в одному напрямку, та незначною кількістю фрібробластів. Також відмічено наявність еластичних волокон у місцях скупчення колагену.

В обстежених без оперативних втручань у минулому характерна наявність осередків інорільтрації, які складалися з лімфоцитів, плазмоцитів, невеликої кількості сегментоядерних лейкоцитів (рис. 2). Крім того, зареєстровано скупчення фрібробластів, сполучна тканина була рихла, колагенові волокна йшли у різних напрямках, еластинових волокон не було.

Таким чином, гістологічне дослідження злук виявило наявність відмінності у структурі злук залежно від чинника, який викликав їх утворення (оперативне втручання або спайковий процес), а також наявність ознак запального процесу, незважаючи на відсутність його клінічних ознак у жінок без оперативних втручань в анамнезі.

Висновок. Таким чином, проведене дослідження показало, що жінки з трубно-перитонеальним безпліддям мають в анамнезі оперативні втручання на тазових органах, часто повторні; майже всі перенесли один або більше епізодів запального процесу репродуктивних органів; структура спайок в них різниться залежно від етіологічного чинника; гістологічно виявляється запальний процес навіть при відсутності його клінічних ознак й проведеному лікуванні у минулому.

ПЕРСПЕКТИВИ ПОДАЛЬШИХ ДОСЛІДЖЕНЬ. ОТрИмані дані вказують на необхідність врахування наявності чи відсутності хронічного запального процесу при розробці підходів вторинної профрілактики утворення спайок

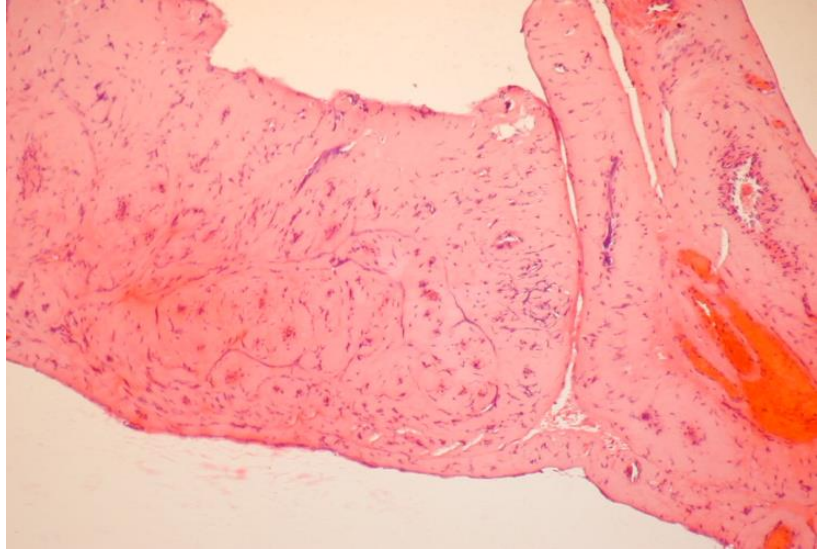

Рис. 1. Рубець утворений дуже щільною волокнистою сполучною тканиною з малою кількістю фібробластів, є поля зору 3 надмірною кількістю колагену. Судини поодинокі, в основному капіляри, вони повнокровні. Забарвлення гематоксиліном-еозином. х100.

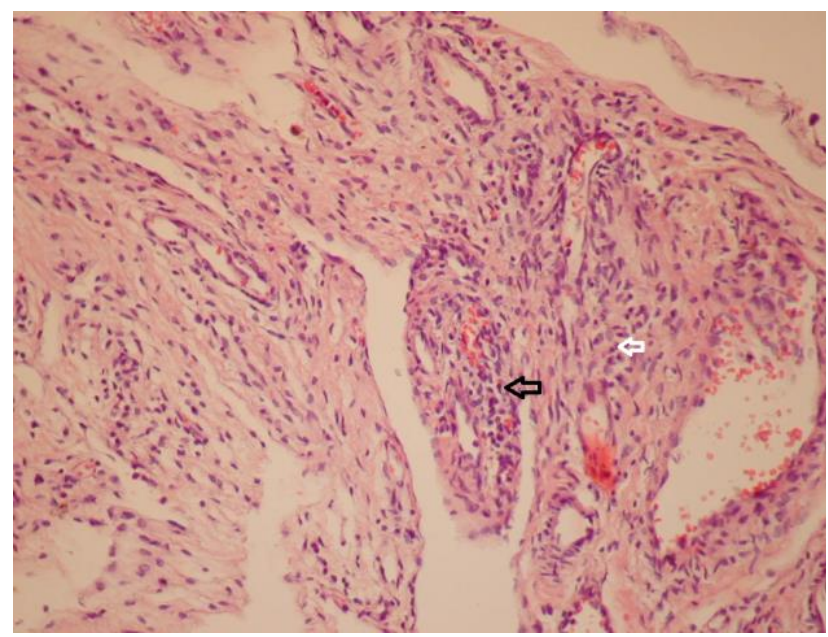

Рис. 2. Вогнищева лімфоплазмоцитарна інфільтрація навколо судин 3 великою кількістю плазмоцитів (вказано стрілками). Забарвлення гематоксиліном-еозином. х200.

у жінок із трубно-перитонеальним безпліддям на етапі післяопераційної реабілітації та лікування безпліддя, й необхідні подальші дослідження у вивченні ефективності лікування трубно-перитонеального безпліддя залежно від етіологічного чинника спайкового процесу у малому тазі.

\section{СПИСОК ЛІТЕРАТУРИ}

1. Таран О. А. Сучасні підходи до лікування та профрілактики післяопераційного спайкового процесу / О. А. Таран // Репродуктивное здоровье женщины. - 2006. - № 4 (29). - С. 125-127.

2. Гінекологія : підручник ; за ред. Б. М. Венцківського, Г. К. Степанківської, М. Є. Яроцького. - К. : ВСВ «Медицина», 2011. - 422 с. ; Книга II : Гінекологія. - К. : Медицина, 2012. - 352 c.

3. Медведев М. В. Спаечный процесс в гинекологии / М. В. Медведев // Здоровье женщины. - 2015. - № 3 (99). - C. $42-46$.
4. Дубчак A. Є. Стан тазової гемодинаміки у жінок з безплідністю, яка супроводжується хронічним тазовим болем / А. Є. Дубчак, І. С. Лук'янова, І. М. Мандзій // Здоровье женщины. - 2012. - № 2. - С. 169-171.

5. Трубно-перитональное бесплодие у женщин / А. С. Гаспаров, Н. Н. Волков, Р. Г. Гатаулина [и др.] // Проблемы репродукции. - 1999. - № 2. - С. 43-44.

6. Муканов М. У. Острая спаечная кишечная непроходимость, обусловленная висцеропариетальными спайками : автореф. дисс. канд. мед. наук/ М. У. Муканов. - М., 1997. -22 с. 
7. Внутриматочные синехии: современный взгляд на проблему / Ю. Н. Тарасенко, И. А. Салов, Д. Т. Ташухожаева, Д. В. Маршалов // Современные проблемы науки и образования. - 2013. - № 4. - URL : http://www.science-education. $\mathrm{ru} / \mathrm{ru} /$ article/view?id=9924.

8. Медведев М. В. Спаечный процесс в гинекологии / М. В. Медведев // Здоровье женщины. - 2015. - № 3 (99). - C. $42-46$.

9. Бойчук А. В. Особливості фрункціональних порушень гіпосрізарно-яєчникової системи у жінок з запальними процесами придатків матки / А. В. Бойчук // ПАГ. - 1997. № 6. - С. 95-98.

10. Hulka J. F. Classification of adnexal adhesions: a proposal and evaluation of its prognostic value / J. F. Hulka, K. Omran, G. S. Berger // Fertil. Steril. - 1978. - Vol. 30. - P. 661-665.

11. Оценка выраженности спаечного процесса в брюшной полости / Н. И. Аюшинова, И. А. Шурыгина, М. Г. Шурыгин, Е. В. Глинская // Сибирский медицинский журнал (Иркутск). - 2014. - № 7. - С. 10-14.

12. Злукова хвороба в гінекології : від патогенезу до профрілактики : метод. рек. / [В. К. Кондратюк, Н. О. Ємець, Н. Д. Коблош та ін.]. - К., 2010. - 4 с.

13. Волянська А. Г. Патогенетичне обґрунтування профрілактики спайкового процесу при гінекологічних операціях ужінок репродуктивного віку (клініко-екпериментальне дослідження) : авторефр. дис. на здобуття наук. ступеня канд. мед. наук. - К., 2016. - 21 с.

14. Чермак I. І. Емпірична протизапальна терапія гострого сальпінгоофориту / І. І. Чермак // Актуальні питання педіатрії, акушерства, та гінекології. - 2015. - № 2. - С. 187-190. DOI: https://doi.org/10.11603/24116-4944.2015.2.4820.

15. Панкова Е. О. Современные подходы к лечению гнойно-септических заболеваний женских половых органов /
Е. О. Панкова // Вестник Росс. ассоц. акушеров-гинекологов. - 2001. - № 1. - C. 32-33.

16. Dinarello C. A. Interleukin-1 in the pathogenesis and treatment of inflammatory diseases / C. A. Dinarello // Blood. 2011. - Vol. 117, No. 14. - P. 3720-3732.

17. Postoperative inflammation in the abdominal cavity increases adhesion formation in a laparoscopic mouse model / R. Corona, J. Verguts, R. Schonman [et al.] // Fertil. Steril. 2011. - Vol. 95. - P. 1224-1228.

18. Ромащенко О. В. Запальні захворювання органів малого таза у юних жінок / О. В. Ромащенко // Педіатрія, акушерство та гінекологія. - 1999. - № 6. - С. 113-117.

19. Стрижаков А. Н. Гнойно-воспалительные заболевания придатков матки / А. Н. Стрижаков, Н. М. Подзолкова. - М. : Медицина, 1996. - 256 с.

20. Дубчак А. Е. Неспецисрические воспалительные заболевания органов малого таза у женщин / А. Е. Дубчак, А. В. Милевский, Е. Н. Довгань // Здоровье женщины. - 2013. - № 2. - C. 51-55.

21. Зароченцева Н. В. Воспалительные заболевания органов малого таза у женщин (обзор литературы) / Н. В. Зароченцева, А. К. Аршакян, Н. С. Меньшикова // Гинекология. - 2013. - Т. 15, № 4. - С. 65-69.

22. Бойков М. В. Исследование проходимости маточних труб и оценка состояния полости матки методом контрастной ультразвуковой гистеросальпингограсрии с использованием анэхогенных и гиперэхогенных контрастных веществ / М. В. Бойков // Акушерство и гинекология. - 1998. - № 1. - C. 29-30.

23. Стрижаков А. Н. Клиническая трансвагинальная эхография / А. Н. Стрижаков, А. И. Давыдов. - М. : Медицина, 1997. - 306 с.

\section{REFERENCES}

1. Taran, O.A. (2006). Suchasni pidkhody do likuvannia ta profilaktyky pisliaoperatsiinoho spaikovoho protsesu [Modern approaches to the treatment and prevention of postoperative adhesive process]. Reproduktivnoye zdorovye zhenshchiny Woman's Reproductive Health, 4 (29), 125-127 [in Ukrainian].

2. Ventskovskyi, B.M., Stepankivska, H.K., \& Yarotskyi, M.Ye. (Eds.). (2011). Hinekolohiia: pidruchnyk [Gynecology: a textbook]. Kyiv: VSV Medytsyna [in Ukrainian].

3. Medvedev, M.V. (2015). Spayechnyy protsess v ginekologii [Adhesions in gynecology]. Zdorovye zhenshchiny - Women's Health, 3 (99), 42-46 [in Russian].

4. Dubchak, A.Ye., Lukyanova, I.S., \& Mandziy, I.M. (2012) Stan tazovoi hemodynamiky u zhinok z bezplidnistiu, yaka suprovodzhuietsia khronichnym tazovym bolem [State of pelvic hemodynamics in women with infertility, which is accompanied by chronic pelvic pain]. Zdorovye zhenshchiny - Women's Health, 2, 169-171 [in Ukrainian].

5. Gasparov, A.C., Volkov, H.G., Gataulina, R.G., \& Melikyan, A.G. (1999). Trubno-peritonalnoye besplodiye u zhenshchin [Tuboperitoneal infertility in women]. Problemy reproduktsii - Problems of Reproduction, 2, 43-44 [in Russian].

6. Mukanov, M.U. (1997). Ostraya spayechnaya kishechnaya neprokhodimost, obuslovlennaya vistseropariyetalnymi spaykami [Acute adhesive intestinal obstruction due to visceroparietal adhesions]. Candidate's Extended abstract. Moscow [in Russian].

7. Tarasenko, Yu.N., Salov, I.A., Tashukhozhayeva, D.T., \& Marshalov, D.V. (2013). Vnutrimatochnyye sinekhii: sovremennyy vzglyad na problemu [Intrauterine synechia: a modern view on the problem]. Sovremennyye problemy nauki i obrazovaniya - Modern Problems of Science and Education, 4. Retrieved from: http://www.science-education.ru/ru/article/ view?id=9924 [in Russian].

8. Medvedev, M.V. (2015). Spayechnyy protsess v ginekologii [Adhesions in gynecology]. Zdorovye zhenshchiny - Women's Health, 3 (99), 42-46 [in Russian].

9. Boichuk, A.V. (1997). Osoblyvosti funktsionalnykh porushen hipofizarno-iaiechnykovoi systemy u zhinok $z$ zapalnymy protsesamy prydatkiv matky [Features of functional disorders of the pituitary-ovarian system in women with inflammatory processes of the appendages of the uterus]. PAG - POG, 6, 95-98 [in Ukrainian].

10. Hulka, J.F., Omran, K., \& Berger, G.S. (1978). Classification of adnexal adhesions: a proposal and evaluation of its prognostic value. Fertil. Steril., 30, 661-665.

11. Ayushinova, N.I., Shurygina, I.A., Shurygin, M.G., \& Glinskaya, Ye.V. (2014). Otsenka vyrazhennosti spayechnogo protsessa $v$ bryushnoy polosti [Evaluation of the severity of adhesions in the abdominal cavity]. Sibirskiy meditsinskiy zhurnal (Irkutsk) - Siberian Medical Journal (Irkutsk), 7, 10-14 [in Russian].

12. Kondratiuk, V.K., Yemets, N.O., Koblosh, N.D., Arkhipova, N.A., Hryhorovych, L.V., \& Cherkova, L.O. (2010). Zlukova khvoroba $v$ hinekolohii: vid patohenezu do profilaktyky (metodychni rekomendatsii) [Adhesive disease in gynecology from pathogenesis to prevention (guidelines)]. Kyiv [in Ukrainian].

13. Volianska, A.H. (2016). Patohenetychne obhruntuvannia profilaktyky spaikovoho protsesu pry hinekolohichnykh 
operatsiiakh u zhinok reproduktyvnoho viku (klinikoekperymentalne doslidzhennia) [Pathogenetic substantiation of prevention of adhesion process in gynecological operations in women of reproductive age (clinical and experimental study)]. Candidate's Extended abstract. Kyiv [in Ukrainian].

14. Chermak, I.I. (2015). Empirychna protyzapalna terapiia hostroho salpinhooforytu [Empirical anti-inflammatory therapy of acute salpingophoritis]. Aktualni pytannia pediatrii, akusherstva, ta hinekolohii - Current Issues in Pediatrics, Obstetrics, and Gynecology, 2, 187-190. DOI: https://doi.org/10.11603/241164944.2015.2.4820 [in Ukrainian].

15. Pankova, Ye.O. (2001). Sovremennyye podkhody k lecheniyu gnoyno-septicheskikh zabolevaniy zhenskikh polovykh organov [Modern approaches to the treatment of purulent-septic diseases of the female genital organs]. Vestnik Ros. assots. akusherov-ginekologov - Bulletin Ros. assoc. obstetriciangynecologists, 1, 32-33 [in Russian].

16. Dinarello, C.A. (2011). Interleukin-1 in the pathogenesis and treatment of inflammatory diseases. Blood, 117 (14), 37203732.

17. Corona, R., Verguts, J., Schonman, R., Binda, M.M., Mailova, K., \& Koninckx, P.R. (2011). Postoperative inflammation in the abdominal cavity increases adhesion formation in a laparoscopic mouse model. Fertil. Steril., 95, 1224-1228.

18. Romashchenko, O.V. (1999). Zapalni zakhvoriuvannia orhaniv maloho tazu u yunykh zhinok [Inflammatory diseases of the pelvic organs in young women]. Pediatriia, akusherstvo ta hinekolohiia - Pediatrics, Obstetrics and Gynecology, 6, 113117 [in Ukrainian].

19. Strizhakov, A.N., \& Podzolkova, N.M. (1996). Gnoynovospalitelnyye zabolevaniya pridatkov matki [Pyo-inflammatory diseases of the uterus]. Moscow: Meditsina [in Russian].

20. Dubchak, A.Ye., Milevskiy, A.V., \& Dovgan, Ye.N. (2013). Nespetsificheskiye vospalitelnyye zabolevaniya organov malogo taza u zhenshchin [Nonspecific inflammatory diseases of the pelvic organs in women]. Zdorovye zhenshchiny - Women's Health, 2, 51-55 [in Russian].

21. Zarochentseva, N.V., Arshakyan, A.K., \& Menshikova, N.S. (2013). Vospalitelnyye zabolevaniya organov malogo taza u zhenshchin (obzor literatury) [Inflammatory diseases of the pelvic organs in women (literature review)]. Ginekologiya-Gynecology, 15 (4), 65-69 [in Russian].

22. Boykov, M.V. (1998). Issledovaniye prokhodimosti matochnikh trub i otsenka sostoyaniya polosti matki metodom kontrastnoy ultrazvukovoy gisterosalpingografii s ispolzovaniyem anekhogennykh i giperekhogennykh kontrastnikh veshchestv [Examination of the fallopian tubes and the uterus state estimation cavity by ultrasonic contrast hysterosalpingography using anehogennoe and hyperechoic contrast agent]. Akusherstvo i ginekologiya - Obstetrics and Gynecology, 1, 29-30 [in Russian].

23. Strizhakov, A.N., \& Davydov, A.I. (1997). Klinicheskaya transvaginalnaya ekhografiya [Clinical transvaginal echography]. Moscow: Meditsina [in Russian]. 